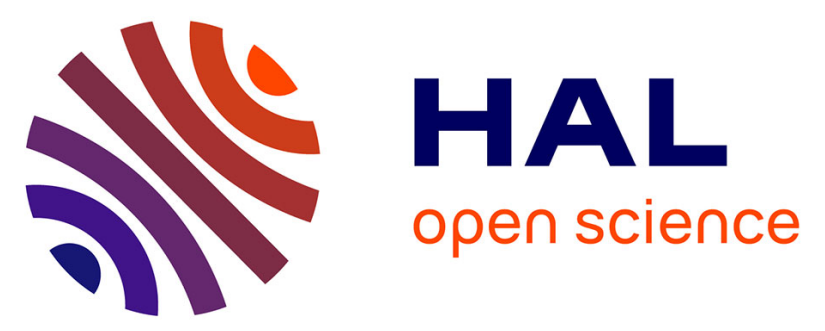

\title{
Analysis of the downward trend in document supply in pharmacology: a case study from INIST in France (part 1)
}

Chérifa Boukacem-Zeghmouri, Thierry Lafouge, Pascal Bador, Hélène Prost, Joachim Schöpfel

\section{To cite this version:}

Chérifa Boukacem-Zeghmouri, Thierry Lafouge, Pascal Bador, Hélène Prost, Joachim Schöpfel. Analysis of the downward trend in document supply in pharmacology: a case study from INIST in France (part 1). Interlending and Document Supply, 2006, 34 (4), pp.177-185. 10.1108/02641610610714768 . sic_00175380

\author{
HAL Id: sic 00175380 \\ https://archivesic.ccsd.cnrs.fr/sic_00175380
}

Submitted on 27 Sep 2007

HAL is a multi-disciplinary open access archive for the deposit and dissemination of scientific research documents, whether they are published or not. The documents may come from teaching and research institutions in France or abroad, or from public or private research centers.
L'archive ouverte pluridisciplinaire HAL, est destinée au dépôt et à la diffusion de documents scientifiques de niveau recherche, publiés ou non, émanant des établissements d'enseignement et de recherche français ou étrangers, des laboratoires publics ou privés. 


\title{
Analysis of the downward trend in document supply in pharmacology: a case study from INIST in France (part 1)
}

\author{
Chérifa Boukacem-Zeghmouri \\ Pascal Bador \\ Thierry Lafouge \\ Hélène Prost \\ Joachim Schöpfel
}

\section{Keywords}

Document supply, Impact Factor, Serials, Electronic Resources, Longitudinal Study, INIST

\begin{abstract}
Purpose: The article investigates the evolution of document supply of print serials.

Approach: The study is based on data from INIST-CNRS - document supply requests and access to electronic resources - of 95 serials with JCR impact factors in pharmacology. Data were collected from 1992 to 2003.

Findings: The results distinguish four groups of serials each with a different evolution of supply requests. Nevertheless, the overall decline from 1999 is a global phenomenon linked to growing access to online journals and there seems little likelihood of a slowdown for the next few years.

Originality: This is the first of three articles on a longitudinal study over 12 years on different aspects of the relationship between document supply and impact factor (citations) in pharmacology, a scientific domain with a high use of scientific information.
\end{abstract}

\section{Introduction, context and issues}

This paper is the outcome of a study conducted by a group of researchers and professionals from different disciplines on a particular issue: trends in indicators concerning scientific serials as a vehicle for disseminating traditional scientific information, in the context of digital libraries.

Two further papers are to be released, pursuing our analysis of the results obtained after processing the data to which we had access. The first of these papers will focus on the growing dissociation of document orders from citations, as reflected by online search data. The second will analyse trends in demand for pharmaceutical journals from INIST customers.

We should point out here that this paper is not the first to address this theme, since it reflects an ongoing debate on flows of scientific information as recorded since 2000 by INIST, the leading French document supply service (Schöpfel, 2003).

Working from a well-defined corpus of journals requested through document supply systems, our previous publications (Bador and Petit, 1998, Bador et al., 2000 and 2002), essentially focused on the relevance of the well known bibliometric indicator known as the "impact factor", in a print environment. Using the results of these studies, we were able to measure the, sometimes relative, importance of the impact factor within a scientific community and 
thus to pinpoint its relative influence on patterns in INIST article requests. These results also underlined INIST's key role in document suply in France, and as a scientific library for the research community.

As our discussions progressed, we broadened their scope to include the present-day context, i.e., patterns in the circulation of scientific information and their significance in the digital age.

The topic at issue relates to a question that has already been analysed in the literature: the downward trend in supply of print documents as compared to the development of electronic resources (Goodier and Dean, 2004, Jackson, 2004, Kidd, 2003, Salaün et al., 2000). The drop in document supply by INIST is demonstrated by available statistics, as shown in the graph below (Figure 1).

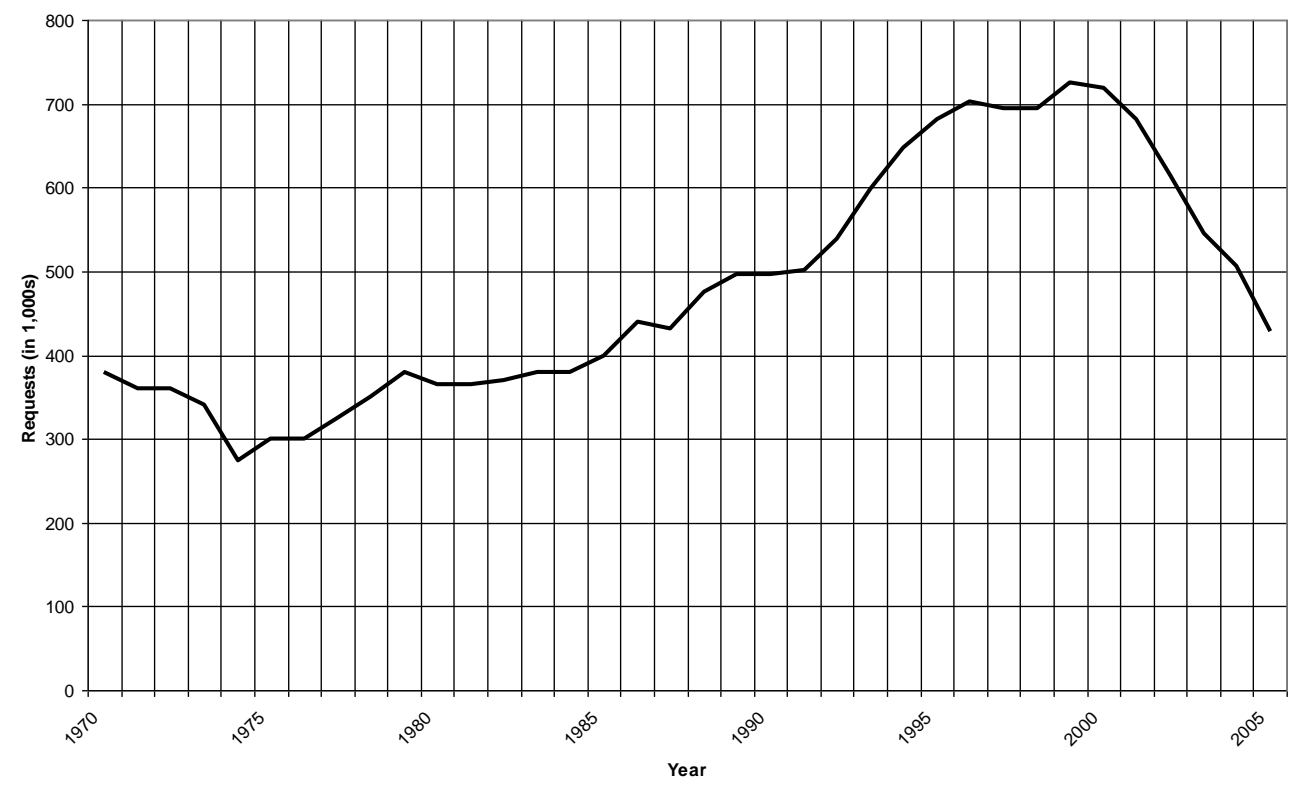

Figure 1: Articles ordered from INIST, 1970 to 2005

These data show that demand for articles from INIST (in all fields) began to slow down in 1999, with a particularly significant drop from 2001. From 1999 to 2004, document supply decreased by $29 \%$.

This downward trend in document supply had already been observed and analysed in French university libraries (Boukacem, 2003 and 2004). The different professional points of view on the subject were brought to the fore during a meeting on document suply and interlibrary loan organized in Montpellier (Schöpfel, 2005). However, the phenomenon is neither isolated nor specific to the French context, as shown for instance by a recent Spanish study (Echeverria and Barredo, 2005).

In seeking the reasons for this overall decline, a combination of several factors must be considered which, since 1999, have helped to shape the context in which the decline has occurred:

- Firstly, the appearance of e-resources in science and medicine on the Web, sometimes as experiments (Hunter, 1996). These resources became increasingly visible to researchers as they were enriched and better organized (Chartron, 2002). 
- In parallel to this supply-side trend, the arrival of the Internet in French university and scientific institutions in 1995 and the expansion of computerized facilities resulted in new uses and practices in connection with the use of electronic resources, and especially electronic journals, for research purposes (Mahé, 2002).

- Finally, looking from the economic angle, the trend was supported by the establishment of the French Academic consortium COUPERIN ${ }^{1}$ that was launched in 1999. As a result online scientific literature became increasingly available to French researchers.

We can therefore make the assumption, for the purposes of our study, that 1999 was the year when digital information broke away from print. Given this macro-analysis of declining demand, our aim here is to perform a micro-analysis in order to identify the factors associated with it.

However, as indicated earlier, we have restricted our analysis to the well-defined field of pharmacology, both for the purpose of our study and because this particular field is of interest per se because of its high use of scientific information.

Our analysis drew on the statistical data processing performed for a corpus of pharmaceutical journals from which single article copies had been requested for 12 consecutive years from 1992 to 2003. This approach provided us with an exhaustive and fully representative framework to analyse the context at issue.

\section{The sample of 95 pharmaceutical journals}

Our starting point was a corpus of 292 pharmaceutical journals selected during our study of quality criteria in scientific journals, published in 1998 (Bador and Petit, 1998). Since our aim was to work on trends in INIST supply of the most significant international pharmaceutical journals over several years, we narrowed our selection to make up a representative sample.

To do so, we used the ISI database Journal Citation Reports (JCR, www.isinet.com), an indispensable international reference. From the selection of journals under the "Pharmacology and Pharmacy" heading, we selected the 95 journals having an impact factor and a citation half-life for the period from 1992 to 2003. These were also journals from which copies of articles had been requested from INIST.

The INIST catalogue provided bibliographic information for each journal: title, ISSN, publisher, country of publication, language of publication, language of abstracts, URL, scientific domain, external location and frequency. The INIST document supply database provided the number of requests of single items for each journal per year, together with information about customers.

\section{The decline in INIST document supply orders}

To address our chosen topic, we needed to consider a changing context that cuts across the three subject areas that were essential to our analysis of the corpus - orders for journal articles from INIST, trends in the supply of electronic publications, and customer typology.

\footnotetext{
${ }^{1}$ Consortium Universitaire de Périodiques Numériques, most important national consortium of French universities and research organisations, see www.couperin.org
} 
Based on the data supplied by INIST, we were able to represent trends in demand for documents from our corpus of 95 international pharmaceutical journals over 12 years (1992 to 2003).

Figure 2 indicates that the general decline in document ordering from INIST also concerns orders for pharmaceutical journal articles.

A comparison of the curves in Figures 1 and 2 shows that in both cases, the decline begins at the same time after the same peak in demand. Moreover, in both cases, the decline is continuous and proportionately identical.

A closer analysis of the processed data from our sample of 95 pharmaceutical journals shows that, like the overall demand curve in Figure 1, 1999 was the critical year when demand, after increasing for several years (+5\% in 1999), went into a steady decline. From 1999 to 2004, INIST recorded a $33 \%$ drop in orders for pharmaceutical articles.

The largest drop during this period (-10.5\%) occurred in 2003 (see Figure 2).

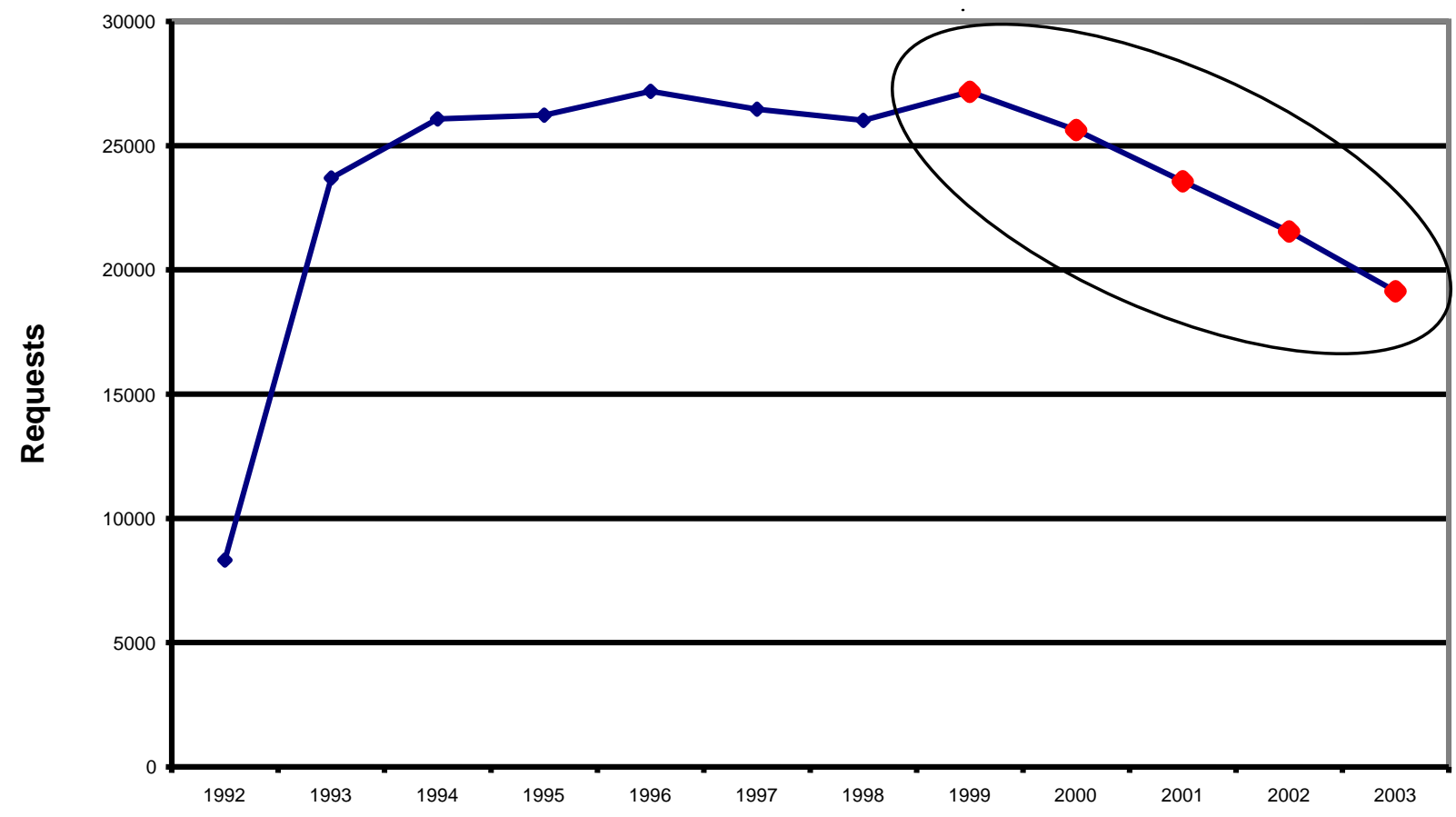

Figure 2: Pharmaceutical journal articles ordered from INIST, 1992 to 2003

\section{Typology of the journals}

We decided to draw up a typology of the 95 journals in terms of ordering rates (requests). In order to compare the evolution of requests between the different journals, we first calculated the percentage of orders per year for each title, and then a linear regression for each of the 95 order distributions over the years from 1999 to 2003. We chose the year 1999 because, as explained above, this was a critical year for the understanding of the decline in document supply requests. 
In the following, we describe briefly the statistical approach for this analysis. For each journal of our sample, we draw a regression line fitting best with the real evolution of the supply of requests from 1999 to 2003, applying the mathematical procedure of the least squares. A visual comparison of the result revealed more or less significant differences between this best-fitting line and the points of the real curve. Therefore we determined how well the regression fits by the widely used statistic called "coefficient of determination" (Pearson test, "multiple correlation coefficient"), $\mathrm{R}^{2}$, that explains how close the points are to the line, and then compared the results with the standard statistical tables, in order to evaluate if the differences were acceptable with a statistical risk of $5 \%$.

Note that a coefficient $<0$ means decreasing orders, and a coefficient $>0$ indicates increasing requests. We then ranked the 95 journals in ascending order of the linear regression coefficient (see the table in annex), as shown in Figure 3. The coefficient varies from $-25 \%$ (average decline of about $2 \%$ per year) to $+10 \%$ (average increase of about $0.8 \%$ per year). Only one journal, "Cardiovascular Drug reviews", had an entirely atypical rate of increase of more than $30 \%$.

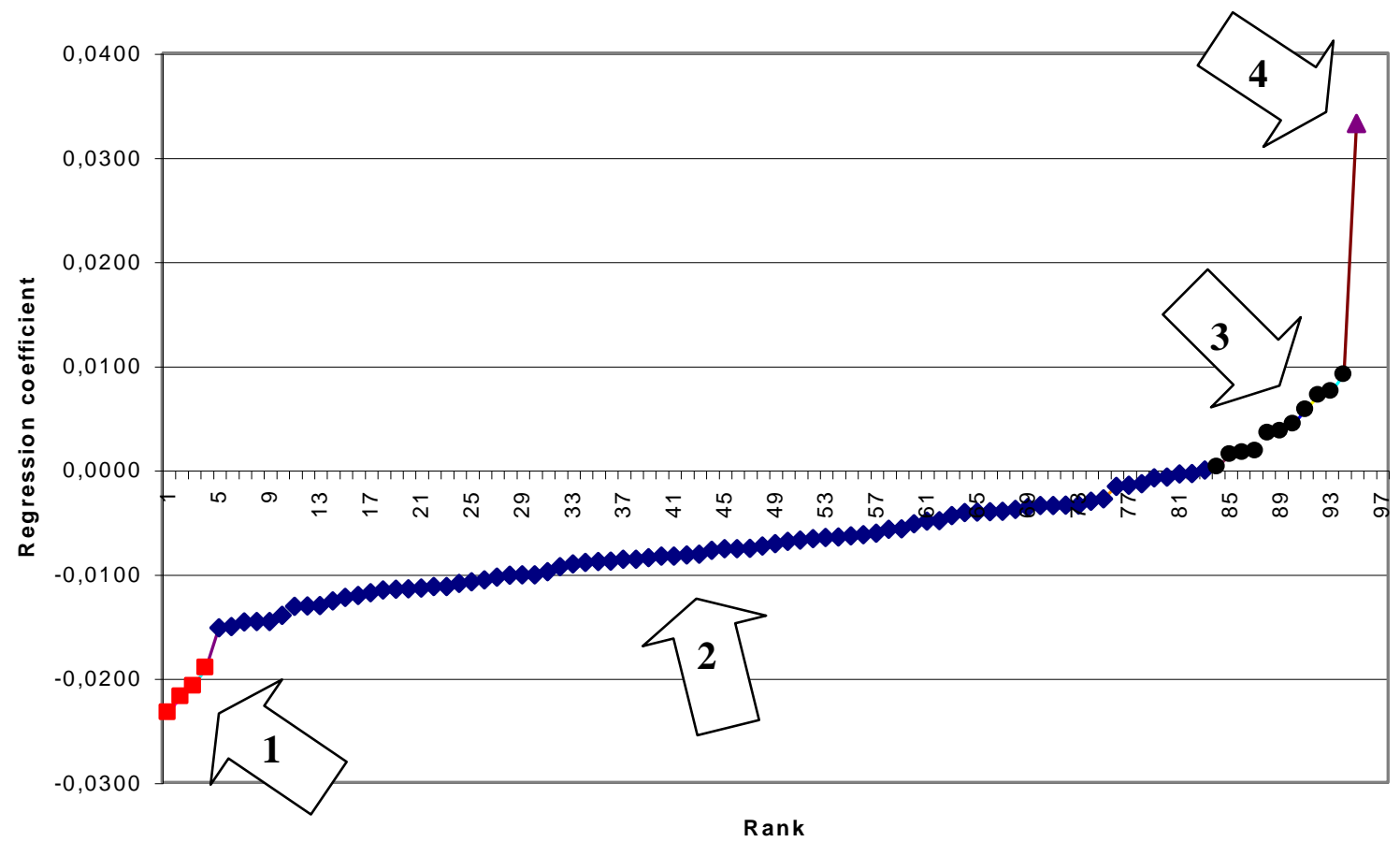

Figure 3: The 95 journals ranked by linear regression coefficient

Figure 3 clearly shows four groups of different sizes and characteristics:

1. The first group contains 4 serials with rapidly declining requests.

2. The second group - the most important - contains 79 journals with a modest or insignificant decline of requests.

3. The third group includes 11 journals with a slight or moderate increase of requests.

4. Finally, one journal has a rather high increase of requests.

All groups are described below.

To take our analysis further, we calculated for each group the average regression coefficient and the coefficient of variation that reflects the heterogeneous nature of the distribution (in 
percentage). Additionally, we searched the sample serials in the French Union Catalogue (SUDOC) $^{2}$ to determine their presence and access in the French university and research libraries.

\subsection{Rapidly declining requests}

The first group contains four journals with a rapidly declining ordering rate (Figure 4).

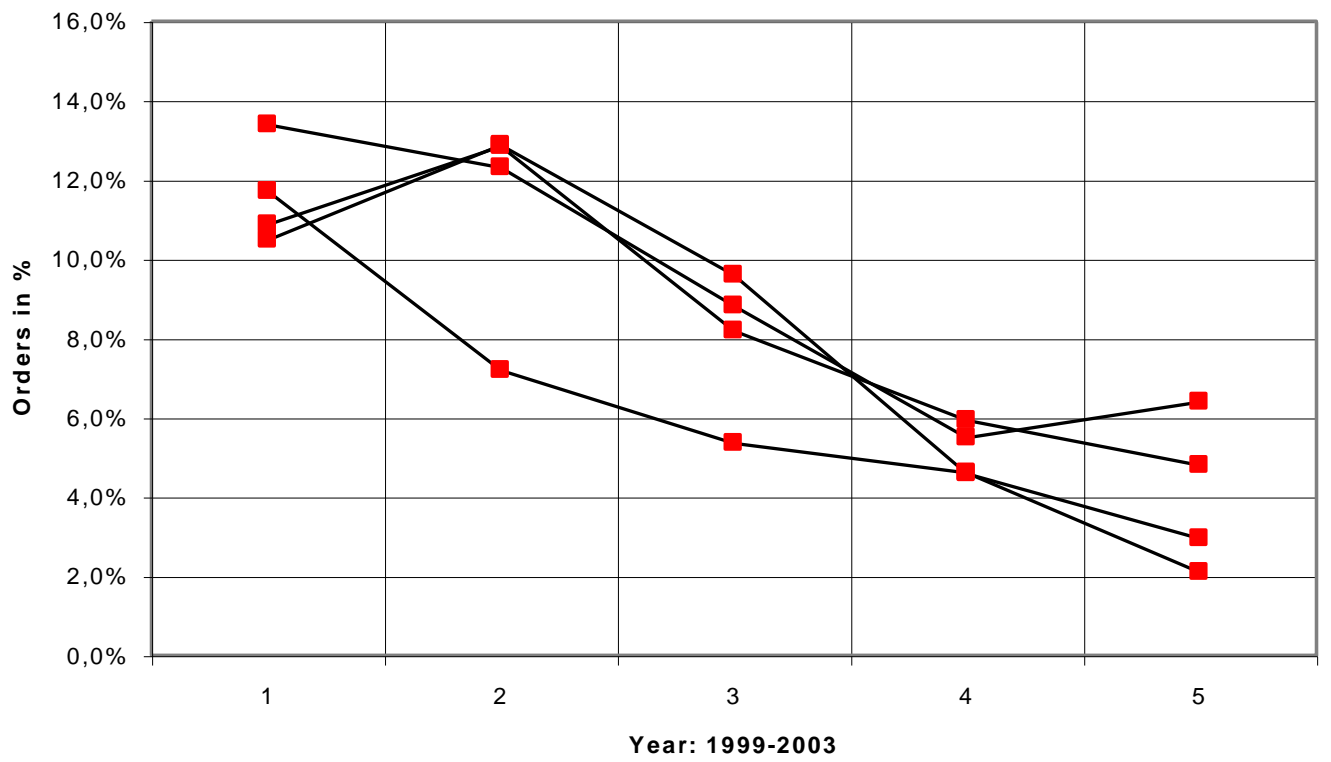

Figure 4: Group 1 journal orders, 1999 to 2003

The average coefficient of the $1^{\text {st }}$ group is -0.02 , i.e. a $2 \%$ drop over 5 years, with a small statistical coefficient of variation of $7.3 \%$.

The considerable drop in orders to INIST concerning three of the four journals in this group ( $4 \%$ of the sample) is accounted for by the fact that these titles were no longer issued in 19992003. The two journals for which orders dropped most sharply, "Immunopharmacology" and "International Journal of Immunopharmacology", both published by Elsevier, merged in 2000 to become a new title, "International Immunopharmacology".

Similarly, the third journal, "Anticancer Drug Design" (from Macmillan) was discontinued in 2001 and became a new journal entitled "Oncology Research, an International Journal incorporating Anticancer Drug Design". No particular event was reported during the period under consideration for the fourth title, "Journal of Controlled Release" (from Elsevier). The drop in the number of orders in this case was undoubtedly due to the early availability (since the first issue in 1984) of an electronic version of the journal.

\subsection{Moderate decline of requests}

\footnotetext{
${ }^{2}$ See http://www.sudoc.abes.fr
} 
The second and most important group contains 79 journals with an ordering rate in moderate decline. Its average coefficient is -0.0066 , i.e. a $0.66 \%$ drop over 5 years, with a large statistical coefficient of variation of $51 \%$ (Figure 5).

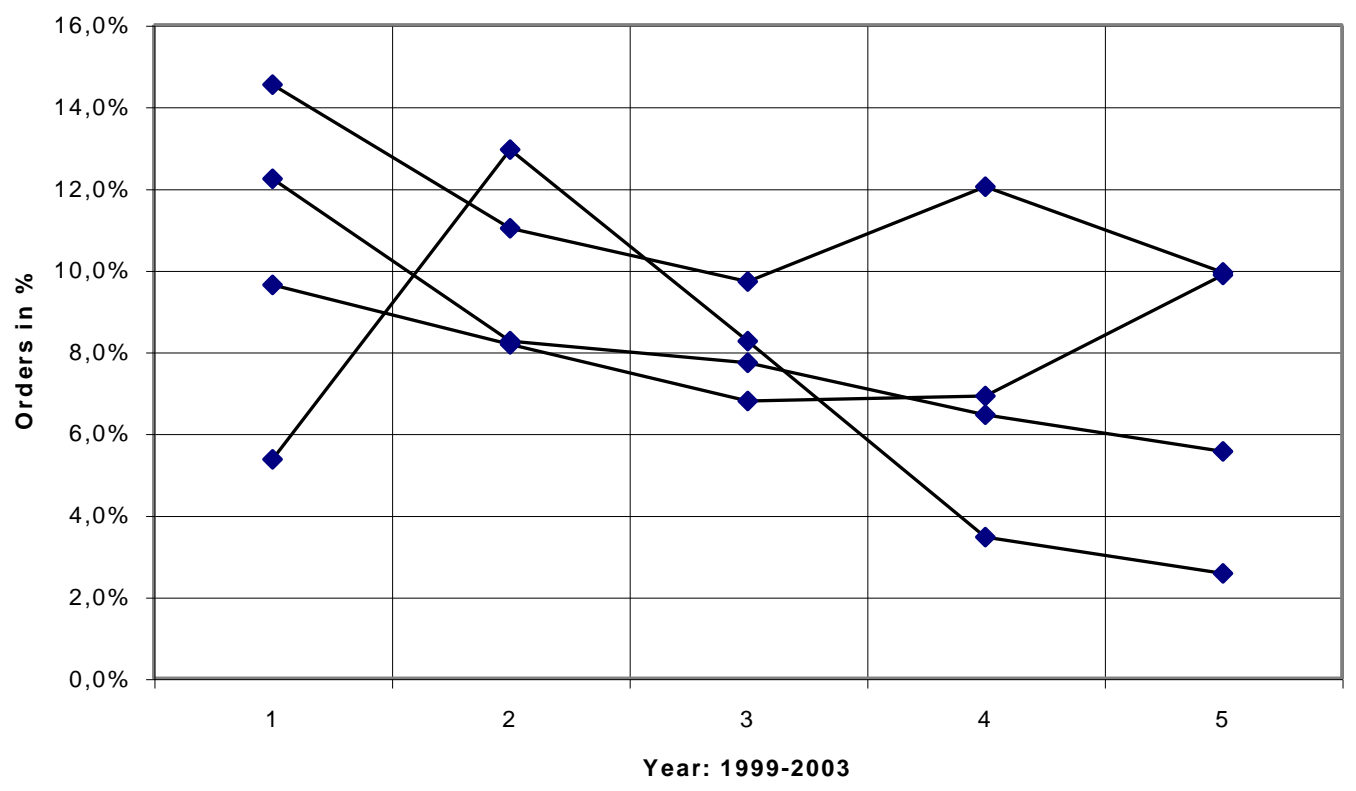

Figure 5: Group 2 journal orders, 1999 to 2003 (sample of 4 journals)

This group of 79 journals (83\% of our sample) with a moderate drop in INIST orders since 1999 is the most representative (but also most heterogeneous) group in the sample. Of the 79 journals, 12 are published by Elsevier (15\%).

The other publishers in the sample only publish 1 to 4 of the journals. From 1999 to 2003, unlike those in Group 1, there were no mergers involving journals in this group. Only three journals were discontinued, "Japanese Journal of Pharmacology" (in 2002), "Quantitative Structure-Activity Relationships" (in 2002), which became "QSAR and Combinatorial Science", and "Pharmacology and Toxicology" (in 2003). Among Group 2 journals, the average moderate drop in INIST orders since 1999 is undoubtedly due to the arrival of electronic versions.

All the studies that have analysed document supply on the electronic resources market agree that 1998-1999-2000 were the years when STM journals began to go online at a much faster rate. These were also the years when academic suppliers of on-line journals became more assertive and better organised. Finally, this was the time when acquisition systems became much more highly structured, with the development of consortia in North America, the UK and Europe (OhioLink, NESLi, COUPERIN).

\subsection{Slight increase of requests}

The third group contains 11 journals with a slight increase in ordering rates (Figure 6): 


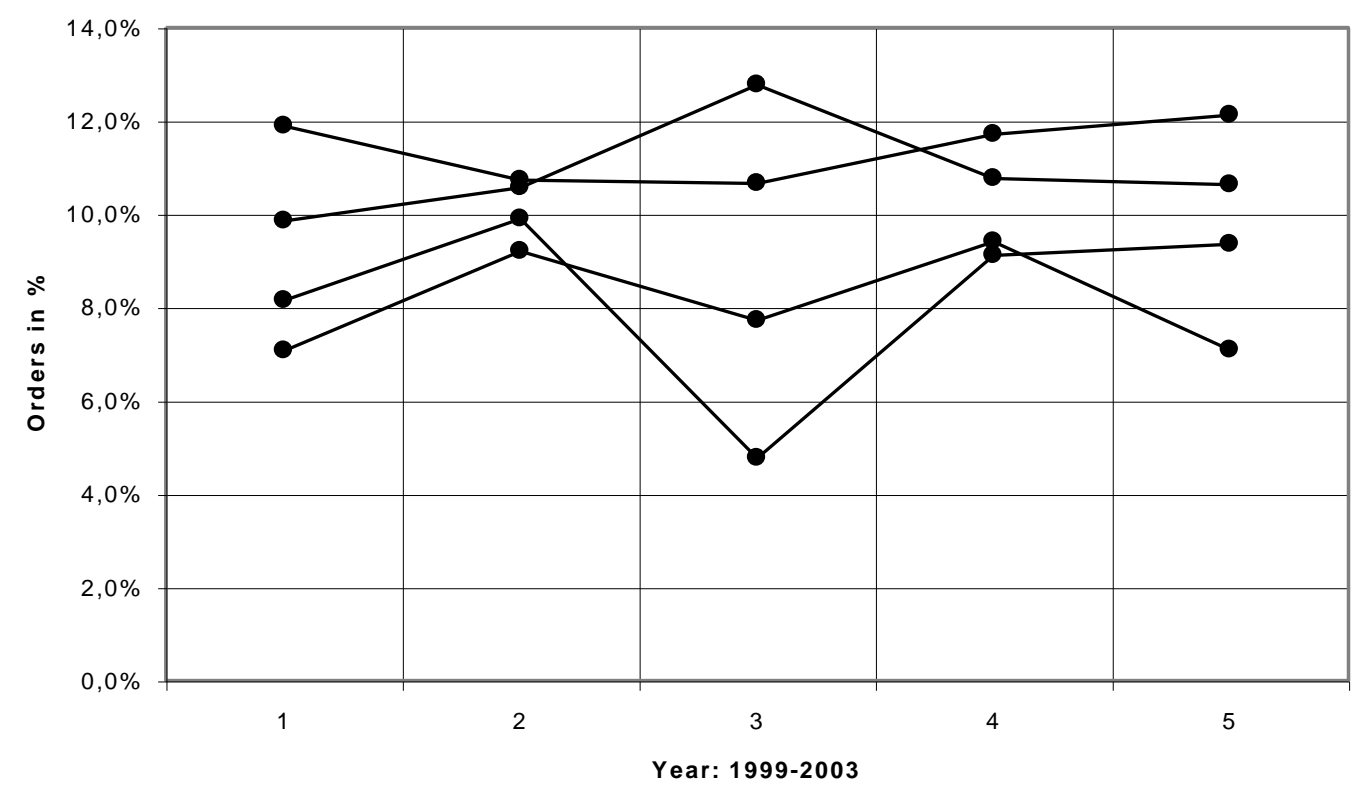

Figure 6: Group 3 journal orders, 1999 to 2003 (sample of 4 journals)

The average coefficient of the $3^{\text {rd }}$ group is 0.042 , i.e. a $4.2 \%$ increase over 5 years, with an important statistical coefficient of variation of $65 \%$ that indicates a rather heterogeneous category.

In this group of 11 journals (12\% of our sample), orders in 1999-2003 were stable or increased slightly. As in Group 2, none of the journals were involved in mergers and none were discontinued during the period. Again, Elsevier leads the field with Wiley (2 journals), while the other major publishers (Dekker, Springer, Thieme, Adis, Wiley, Blackwell) have only one journal in the group.

\subsection{High increase of requests}

Only one journal out of the 95, "Cardiovascular Drug Reviews", is in the group where INIST orders have increased considerably since 1999. 


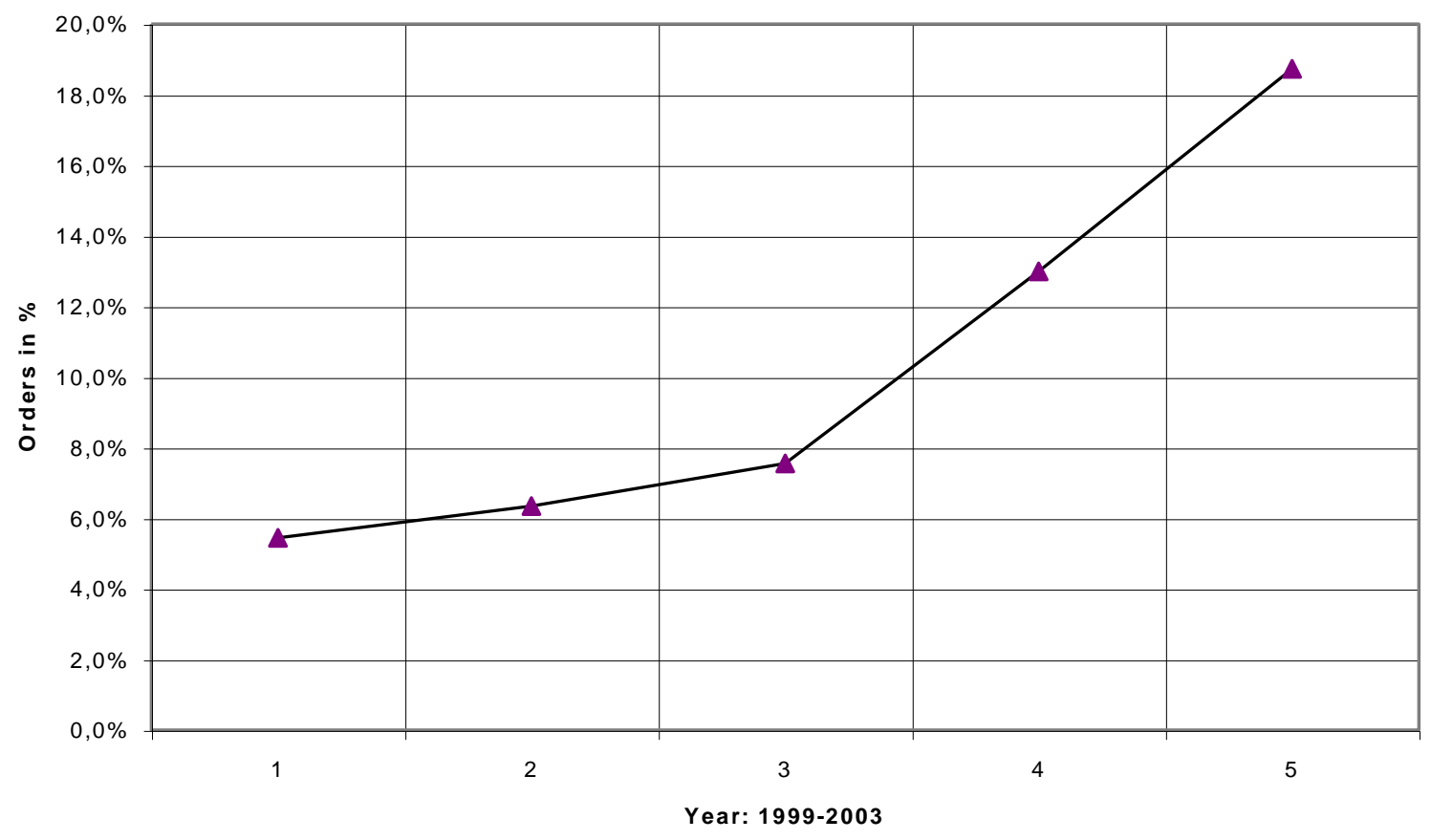

Figure 7: Group 4 journal orders, 1999 to 2003

The full text in electronic format has only been available since 1999 (free access) and since 2000 for subscribers. Only the print journal is available in France, and only in two libraries (INIST and a CNRS laboratory in Nice Sophia-Antipolis). The fact that the University of Lyon cancelled its subscription in 1997 may account for the increase in orders received by INIST since 1999.

\subsection{Comparison of the groups}

Figure 8 shows the average coefficient for these three groups. The variation in Group 2 is exactly the same as the variation for all journals, which is not surprising as Group 2 is representative of the entire corpus. 


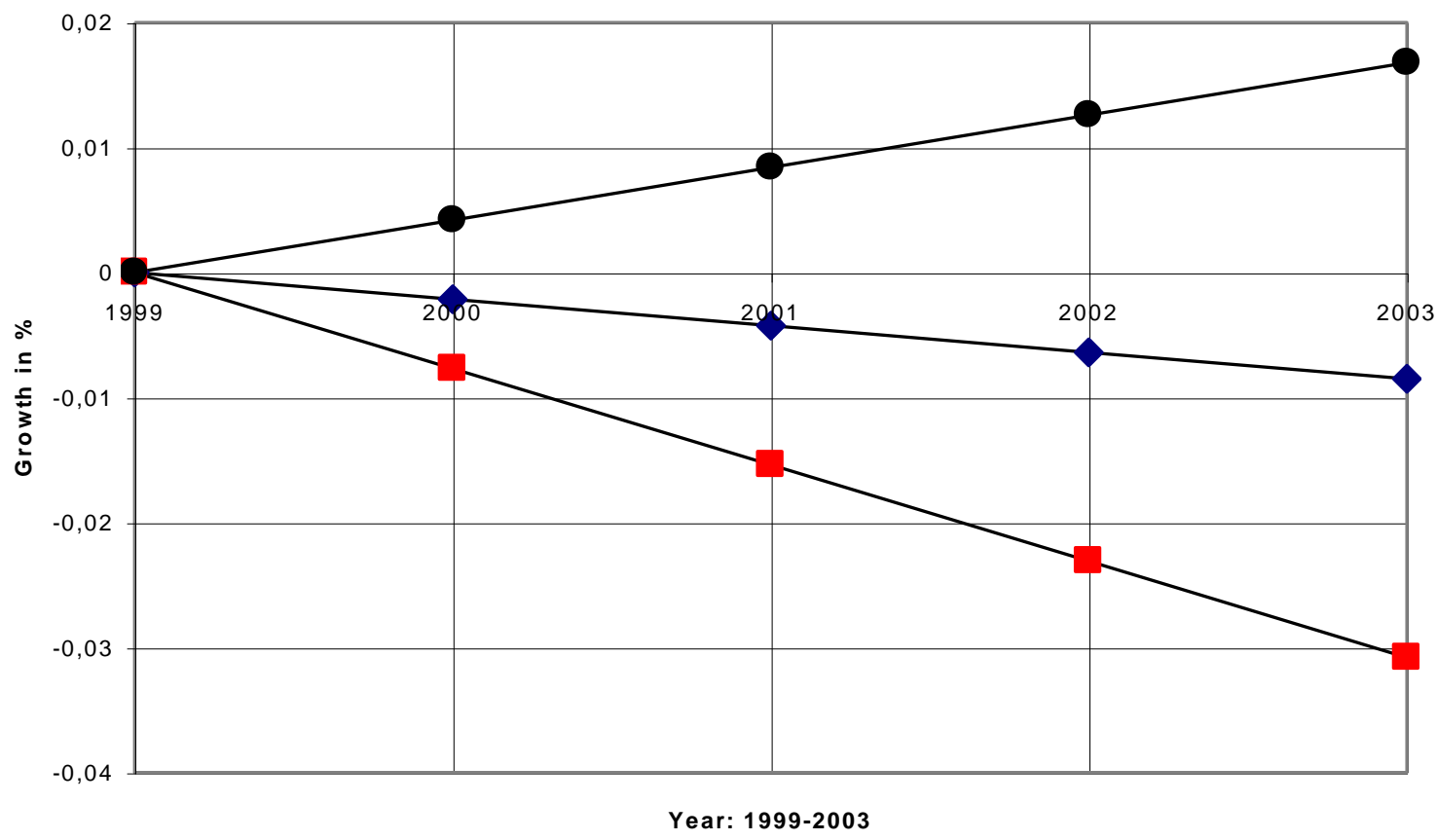

Figure 8: Average increase in orders for journals in Groups 1,2 and 3 (for group 4, see figure 7)

We should also point out that consistently high orders are not linked to high subscription rates. Among the 88 titles where the 2005 subscription price is known, there is only one case where the two are highly correlated: "International Journal of pharmaceutics" from Elsevier which has the second highest subscription rate and which also ranks second in terms of orders received by INIST in 2004 .

\section{Electronic publications: supply and growth patterns}

Most electronic resources are from the commercial publishing sector where revenue and volume sales of electronic publications are growing rapidly, especially in health and science (STM). In this section, we outline the main supply-side characteristics, in order to provide insights into the issues they raise in connection with the decline in article orders from our document corpus.

The first wave of electronic document supply was a direct outcome of the conclusions drawn by the TULIP ${ }^{3}$ experiment. The initial focus was for online versions of printed medical journals, followed by scientific journals. After offering "previews" of journal contents, publishers, with Elsevier in the lead, began to post the full text of their print journals on line. Hypertext links soon became the main source of added value for this new way of disseminating information.

Initially, the boom in electronic versions of print journals in scientific, technical and medical fields (STM) - which include pharmaceuticals - was closely linked to the new mode of production. The range of products on offer grew rapidly. From 1997, the sector entered its "industrial age" (Chartron, 2002). Elsevier, the pioneer in very broad product ranges (over 1000 titles), drew its own lessons from the critical mass generated by the TULIP experiment,

\footnotetext{
${ }^{3}$ TULIP: The University Licensing Program started in 1992 and performed by Elsevier and nine universities in the USA, see http://www.elsevier.com/wps/find/librarians.librarians/tulip
} 
and entirely new electronic titles began to appear on the market alongside electronic versions of print journals. The NewJour site reported an overall increase of 9,846 journals in all disciplines from 1991 to $2001^{4}$. The French COUPERIN ${ }^{5}$ consortium, with a corpus similar to our own, offered in 2004 nearly 2,000 journal titles (Elsevier, Springer Kluwer, Taylor and Francis, Thomson, Wiley) representing an acquisition budget of 16 million euros and no less than 17 million annual full text downloads.

Through its national portals, INIST provides fee-paying or free access for public research laboratories to the electronic versions of thousands of journals in all disciplines. Of these, 128 titles are indexed as pharmacology serials.

\section{Analysis of the decline in orders by customer type}

From the data supplied to us, we identified the customers who have exerted the greatest influence on the overall drop of some $33 \%$ in orders for articles from pharmaceutical journals.

This analysis produced a customer-based distribution of the decline in orders, thus providing a better understanding of what has been happening.

During the period of decline we analysed (1999 to 2003), the largest decline was in the public research sector. Orders from INSERM ${ }^{6}$ medical research, for example, dropped by $88 \%$ from the beginning to the end of the period.

The drop for hospitals, which are among the most frequent customers, was $67 \%$. In higher education, a massive user of COUPERIN, requests dropped by $64 \%$. The $\mathrm{CNRS}^{7}$ laboratories come next, with a drop of $60 \%$.

Requests from other French research organisations and individuals fell by $44 \%$ and $45 \%$ respectively. Finally, requests from the corporate sector were down by $26 \%$.

These figures are consistent with the market trend towards online access to scientific information. The major customer categories described above, where orders are significantly lower, are categories that have opted for on-line access to electronic journal portfolios, through consortiums or other access systems, such as the BiblioINSERM portal ${ }^{8}$. Opting for services of this sort has often enabled this clientele to extend their catalogues and reduce the use of print as well as associated delivery times.

\section{Conclusion}

The decline in orders for pharmaceutical journal articles from INIST is consistent with an overall downward trend in print document supply, which in turn is a consequence of the rapid development of electronic resources and multiple tools and points of access to these resources.

Our study, which was based on a triple analysis of the sector (article orders in pharmaceutics, customer typology and supply from publishers), has led us to draw two main conclusions:

\footnotetext{
${ }^{4}$ See http://www.gort.ucsd.edu/newjour/index.html

${ }^{5}$ See footnote 1 .

${ }^{6}$ French national research organisation in medical sciences.

${ }^{7}$ Most important French national fundamental research organisation with 30,000 scientific and technical staff.

${ }^{8}$ See http://biblioinserm.inist.fr
} 
- Our analysis demonstrates, on the one hand, the impact on the print medium of policies and commercial strategies for electronic scientific publications. The decline in document delivery orders appears to be a symptom of the vertical structure and organisation of the market for scientific information in pharmaceutics, rather than a consequence. As can be seen from the journals in groups 1 and 2, takeovers and mergers between commercial publishers, which entail the disappearance of certain journals, changes in titles or switching to an electronic version only, mainly affect "core titles" that are the most in demand.

- Furthermore, mass online availability of electronic collections and the organisation of feepaying access systems - portals, consortia and so on - have caused entire research communities to move away from print document supply and the various time-related constraints they imply, and towards direct access. The importance of direct access has changed the document search habits - and therefore the ordering patterns - of an entire community. Regardless of its intrinsic quality, a title also becomes important simply because it is available on line.

Beyond our sample, it seems likely that the overall decline of traditional document supply will continue because of the cumulated effect of four factors: All STM publishers are developing the online media (full-text databases). More and more collections are entirely available on the Web (retrospective digitisation of the corpus back to Vol 1 No1). Search engines are continuously improving the access to these materials (Google effect). Finally, the pharmaceutical community, like other scientific communities, changed their research practices from traditional library use to the exploitation of digital resources, through online subscriptions (big deals) or retrieval of freely available material (open access, repositories).

The forthcoming studies will focus on the characteristics of our sample (journals) and of the requests (customers) in order to give empirical evidence of the underlying dynamics of the evolution of document supply.

\section{Bibliography}

Bador, P. and Petit, O. (1998), "Facteur d'impact et indexation dans les bases de données bibliographiques: Comparaison de ces deux critères de qualité pour l'évaluation des revues pharmaceutiques", Journal de pharmacie de Belgique, Vol 53, No 2, pp.71-80

Bador, P., Ben Romdhane, M., Guinet, E. and Lafouge, T. (2000), "Analyse de la circulation des périodiques pharmaceutiques européens: l'exemple du principal fournisseur français de documents", Journal de pharmacie de Belgique, Vol 55, No 4, pp.101-110

Bador, P., Ben Romdhane, M.. and Lafouge, T. (2003), "European pharmaceutical journals: relationship between demand and indexation: the example of the main French document supplier", The Canadian journal of information and library science, Vol 27, pp. 33 - 55

Boukacem, C. (2004), Du prêt entre bibliothèques à la bibliothèque virtuelle : une évolution contrastée des bibliothèques universitaires selon la discipline, Doctoral thesis, University of Lyon 2

Boukacem, C. (2003), "Inter-library loan services and access to electronic resources in French university libraries: a marriage of reason”, Interlending \& Document Supply, Vol 31, No 4, pp. $218-227$ 
Chartron, G. (2002), Les chercheurs et la documentation numérique: nouveaux services et usages, Editions du Cercle de la Librairie, Paris

Echeverria, M. and Barredo, P. (2005), "Online journals: their impact on document delivery", Interlending \& Document Supply, Vol 33, No 3, pp. 145-149

Goodier, R. and Dean, E. (2004), "Changing patterns in interlibrary loan and document supply", Interlending \& Document Supply 2004, Vol 32, No 4, pp. 206-214

Hunter, K. (1996), "Publishing for a digital library - what did TULIP teach us?", The journal of academic librarianship, Vol 22, No 3, pp. 209-211

Jackson, M. (2004), "Will electronic journals eliminate the need for ILL?" Interlending \& Document Supply, Vol 32, No 3, pp. 192-193

Kidd, T. (2003), "Does electronic journal access affect document delivery requests?", Interlending \& Document Supply, Vol 31, No 4, pp. 264-269

Mahé, A. (2002), La communication scientifique en (r)evolution: l'intégration des revues électroniques dans les pratiques informationnelles des chercheurs en sciences de la nature comme révélateur des mutations du modèle traditionnel de la communication scientifique, Doctoral thesis, University of Lyon 1

Salaün, J. M., Lafouge, T. and Boukacem, C. (2000), "How far does demand for scientific articles reflect development in electronic publishing? An example from the Institut de l'Information Scientifique et Technique (France)", Scientometrics, Vol 47, No 3, pp. 561588

Schöpfel, J. (2003), "INIST-CNRS in France: 'a model of efficiency". Interlending \& Document Supply, Vol 31, No 2, pp. 94-103

Schöpfel, J. (2005), "Interlibrary loan and document supply in France - the Montpellier meeting", Interlending \& Document Supply, Vol 33, No 1, pp. 56-58 
Annex: Orders for articles from the 4 pharmaceutical journals in Group 1, 1999 to 2003

\begin{tabular}{|c|c|c|c|c|c|c|c|c|c|c|c|c|c|}
\hline Journal & 99 & 00 & 01 & $\mathbf{0 2}$ & $\mathbf{0 3}$ & $\begin{array}{c}\begin{array}{c}\text { Total } \\
\text { orders }\end{array} \\
1992-2003\end{array}$ & $\begin{array}{l}99 \\
\%\end{array}$ & $\begin{array}{r}00 \\
\%\end{array}$ & $\begin{array}{r}01 \\
\%\end{array}$ & $\begin{array}{r}02 \\
\%\end{array}$ & $\begin{array}{r}03 \\
\%\end{array}$ & REG 99 & Quality \\
\hline IMMUNOPHARMACO & 96 & 118 & 88 & 42 & 27 & 917 & 10.5 & 12.9 & 9.6 & 4.6 & 2.9 & $-2.33 \%$ & 0.78 \\
\hline INT J IMMUNOPHARMACO & 140 & 86 & 64 & 55 & 25 & 1196 & 11.7 & 7.2 & 5.4 & 4.6 & 2.1 & $-2.18 \%$ & 0.93 \\
\hline J CONTROL RELEASE & 522 & 480 & 344 & 214 & 249 & 3901 & 13.4 & 12.3 & 8.8 & 5.5 & 6.4 & $-2.08 \%$ & 0.88 \\
\hline ANTI-CANCER DRUG DES & 77 & 91 & 58 & 42 & 34 & 709 & 10.9 & 12.8 & 8.2 & 5.9 & 4.8 & $-1.90 \%$ & 0.81 \\
\hline
\end{tabular}

\section{The authors}

Chérifa Boukacem-Zeghmouri is Lecturer at Université Charles de Gaulle, Lille 3, UFR IDIST

boukacemc@yahoo.fr

Pascal Bador is Lecturer Université Claude Bernard, Lyon 1 Santé.

Pascal.Bador@univ-lyon1.fr

Thierry Lafouge is Professor at Université Claude Bernard, Lyon 1 Sciences.

Thierry.Lafouge@univ-lyon1.fr

Hélène Prost is Librarian at INIST-CNRS and Specialised in the Evaluation of Collections and Document Supply.

prost@inist.fr

Joachim Schöpfel is Head of the E-publishing and Document Supply Department at INIST-CNRS and Lecturer on Scientific Information at the University of Nancy. 
$\underline{\text { schopfel@inist.fr }}$ 